https://helda.helsinki.fi

\title{
Language endangerment and language documentation in Africa
}

\author{
Lüpke, Friederike
}

Cambridge University Press

2019

Lüpke, F 2019 , Language endangerment and language documentation in Africa . in E Wolff (ed.) , The Cambridge handbook of African linguistics . Cambridge Handbooks in Language and Linguistics , Cambridge University Press , Cambridge , pp. 468-490 . https://doi.org/10.1017/9781108283991.01

http://hdl.handle.net/10138/310912

https://doi.org/10.1017/9781108283991.015

unspecified

acceptedVersion

Downloaded from Helda, University of Helsinki institutional repository.

This is an electronic reprint of the original article.

This reprint may differ from the original in pagination and typographic detail.

Please cite the original version. 
Lüpke, Friederike. Forthcoming. Language endangerment and language documentation in Africa. In: Wolff, Ekkehard (ed.). The Cambridge Handbook of African Linguistics. Cambridge: Cambridge University Press.

\section{Language endangerment and language documentation in Africa}

1 How global is language endangerment?

1.1 The global and the local

Language endangerment and death is seen as a process that operates world-wide. The metaphors used to describe the situations of language change and shift ${ }^{1}$ captured under this umbrella term cast them as a human tragedy of the largest imaginable scale. Yet, when shifting our gaze to Africa, stories of resilience and adaptivity, of mobility, multilingualism and creativity, flank stories of disappearance and extinction. In this introduction I gauge how useful global perspectives on language endangerment and loss (henceforth LEL; see Mufwene forthcoming) are; whether they are really global; and what kind of mould they provide for describing locally anchored practices. A critique of universal scales and models and a quest for different perspectives on communicative practices on the African continent and for new ways to describe and document them is made in the remainder of the introduction, but runs through the chapter, focussing on ontologies, concepts and models of linguistic description and documentation (LDD) and LEL in 2; on sites of linguistic vitality in 3; and on situations of linguistic exclusion and marginalization in 4 . Section 5 briefly explores how new phenomenological approaches may not only serve to capture Africa's linguistic diversity more fully, but how they may contribute to a decolonization of African linguistics and to the conceptualization of new forms of language development.

\subsection{Scales and scale of language endangerment}

Language vitality and endangerment (henceforth LVE; see also UNESCO 2011) on the African continent are not well understood, since there is very little detailed, sociolinguistically informed research on language use available (Djité 2008, 2009). General assessments focus on language endangerment, i.e. they offer judgements on the likelihood of named languages seen as potentially vulnerable continuing to be used in a form that represents an indigenous group's linguistic and cultural heritage. In order to assess endangerment, a number of universal scales and measurements are available, but impressionistic evaluations are widespread. The focus on likelihood of loss, rather than on resilience, as also stressed by Mufwene (forthcoming), originates in justified concerns about language endangerment informed by American and Australian settings. This preoccupation with endangerment goes hand in hand with an essentialist focus on languages, rather than on communicative repertoires and language ecologies, which stems from the history of language description and documentation (LDD). In Africa, this endeavour is intimately linked to colonial practice, a historical contingency that needs to be reflected upon when using concepts and ontologies originating in the colonial period.

The most influential scales of language vitality are meant to be universal. Here, I will only focus on the language vitality and endangerment (LVE) scale proposed by UNESCO (2003). This scale proposes nine factors of LVE, each of them apart from 2 (absolute numbers of speakers) having a graded scale of criteria singling out the language thus assessed as safe, at risk, unsafe, definitely endangered, critically endangered or extinct. The nine factors are:

1. Intergenerational language transmission

\footnotetext{
${ }^{1}$ See Hill (2002) and Perley (2012) for important reflections on the metaphors that underlie LEL research.
} 
2. Absolute number of speakers

3. Proportion of speakers within the local population

4. Trends in existing language domains

5. Response to new domains and media

6. Materials for language education and literacy

7. Governmental and institutional language policies, including official status and use

8. Community members' attitudes towards their own language

9. Amount and quality of documentation

These criteria have been used by a number of researchers to assess LVE of African languages (e.g. Brindle 2015; Légère 2007). Yet, limits of their applicability have been observed by Africanists and other members of the LEL community, including UNESCO itself and several users and respondents to a questionnaire linked to the catalogue (as summarized in UNESCO 2011). I briefly discuss Africaspecific reasons rendering this catalogue of factors problematic before turning to wider epistemological concerns shared by other LEL researchers. It is surprising that the critique of universalist LVE assumptions from an Africanist perspective has not been reflected in their revision yet, although this critique has been vocal and of long date (Dimmendaal 2008; Lüpke 2009, 2015; Mc Laughlin 2008; Mous 2003; Mufwene 2016; Vigouroux \& Mufwene 2008). The following observations are therefore meant as timely invitations for wider dissemination and feedback of African sociolinguistic settings into wider LEL discourses and LVE criteria catalogues.

Let us start with the ideal picture of a safe language through the lens of UNESCO LVE catalogue: this language should be spoken by a not-too-low number of speakers in a given population. It should be used in all communicative domains, including in writing, and be passed on to children by their parents. The language should be viewed positively by its speakers, receive support from the state and benefit from a wide range of language materials.

Such a language does not exist on the African continent. ${ }^{2}$ Yet, this continent hosts close to half of the world's languages and is commonly described as having escaped the scenarios of widespread language death occurring worldwide. A pertinent question must therefore be how we can explain that Africa is affected by LEL at a much smaller scale. This task includes a critical appraisal of universal scales of LEL and the conceptions of language they entail. As Gal (2016) and Irvine (2016) forcefully remind us, universal and standardized scales claim to be a-perspectival (or objective), but in reality never really are. Therefore, in the following, I take up the imaginations of what a thriving language is in the UNESCO LVE catalogue and discuss how the perspective inherent in them is not adequate for many African situations:

- Re 1: Intergenerational transmission is not the most prominent form of language socialisation in many African contexts; peer groups, age classes and professional groups, among other social contexts, are often as important or even more important sites of language acquisition, often resulting in the acquisition of several languages in childhood and life-long learning of languages depending on trajectories of individuals.

\footnotetext{
${ }^{2}$ Even among the largest languages on the continent, only Swahili comes close to this ideal, since it is the official language of Kenya and Tanzania (alongside English), and used at all levels of education in Tanzania, albeit with very limited actual scope in higher education and formal contexts. While a growing number of African states are recognizing indigenous languages as official languages alongside the colonial official languages, this rhetorical move is not translated into real language policies implemented in practice.
} 
- $\operatorname{Re} 2$ : A high number of languages with small speaker numbers is a precondition for linguistic diversity; to correlate small numbers with LEL creates wrong expectations on what makes a thriving linguistic ecology since the assumption of high speaker numbers for healthy languages is based on the model of the monolingual nation state.

- Re 3: Using the proportion of speakers in the local population is based on the ideal of a homogeneous and monolingual community and does not allow accounting for situations of multilingualism that are not characterized by di- or polyglossia; that is, situations where not all of the languages spoken in a setting are associated with high prestige and dominance relative to others.

- Re 4 to 6: Assuming that healthy languages should be used in as many domains as possible, including digital media, and in writing, is based on the out-dated model of the "two solitudes of multilingualism" (Cummins 2008), where multilingualism is conceptualized as consisting of two or more parallel and complete repertoires used in all domains and modalities by all speakers. Multilingualism on the African continent takes many forms and is not confined to urban settings. Multilingualism is particularly widespread in situations of high linguistic diversity.

- $\operatorname{Re} 7$ : Government support does not allow for singling out the most vulnerable languages, because on the African continent, despite some token gestures, only the colonial official languages receive recognition and support.

- $\operatorname{Re} 8$ : While attitudes and ideologies of speakers play an undeniable role for language use, it is erroneous to expect individuals to identify with only one language or to be a member of a clearcut ethnolinguistic community in many African settings.

- $\operatorname{Re}$ 9: The amount of documentary, descriptive and pedagogical materials is so limited and inaccessible to Africans for the majority of situations that this criterion is spurious.

The employment of universal scales is thus not helpful for uncovering the specificities of African sociolinguistic settings, many of which are characterized by great linguistic vitality. With its thriving linguistic diversity and high multilingualism in indigenous languages, Africa presents a picture to which LVE assumptions won from different contexts cannot be applied, starting with the measurements that inform them. The following section explores the reasons for this difference.

\subsection{Limits of the global}

Because of the different colonial experience of most of Africa, the real impact of languages of colonial provenance there (but crucially not their political and cultural capital, see 4), is not as far-reaching as in the birth places of the LEL movement. Africanists agree in emphasizing that the sociolinguistic situation on the African continent - with the exception of Southern Africa - is markedly different from those constellations that have inspired this movement: the Americas, in particular North America, and Australia. Indigenous people on these continents have suffered most from the colonial expansion starting in the $15^{\text {th }}$ century, because of the settlement colonies created there. In these situations, precolonial linguistic diversity has been diminished dramatically, and formerly complex situations have been reduced to a conflictual contrast between dominant settler languages and moribund or endangered indigenous languages. The colonial experience in Africa, although not less traumatic, since associated with the trauma of the transatlantic slave trade, was not characterized by the settlement of large numbers of Europeans, with the crucial exception of Southern Africa, where the impact of German, Dutch and English settlements is still felt today.

Due to their limited reach, though certainly not to lack of imperial intentions, European colonial languages play a much lesser role in LEL of African languages than in situations where a clear clash 
between indigenous (here merely understood as pre-colonial) inhabitants and colonial settlers can be observed, although they have remained the official languages of African states after independence. ${ }^{3}$ The limited role of colonial languages holds particularly for areas with indigenous languages of wider communication that were established prior to the colonial era. Where language shift resulting in decreasing linguistic diversity is observed in Africa, it is often to larger African languages that have such a historical presence in the area concerned (Batibo 2005; Bodomo et al. 2009; Brenzinger 1992) and that already form part of peoples' repertoires. Widespread, but less documented, are shifts to other small languages that do not decrease the levels of linguistic diversity, because speakers remain multilingual, but continuously adapt their multilingual repertoires to changing circumstances. Such shifts occur, for instance, through the incorporation of strangers into small-scale societies or movement of small groups and of individuals that with time result in a change in their linguistic repertoires. Much of this movement remains completely undertheorized in multilingualism and language contact research, since it is at loggerheads with its dominant metaphor of contact between neighbouring groups and its common distinction of first- and second language speakers (e.g., Trudgill 2011) ${ }^{4}$. In contexts where, for instance, exogynous marriage entails longstanding exchanges of women, whose directionality can be reversed in the next generation in the case of cross-cousin marriage, multilingualism is deeply embedded in the fabric of society. ${ }^{5}$ In these contexts, there is not one particular linguistic identity or practice that can be singled out as typifying ethnolinguistic identity - rather, being an adaptive multilingual expresses the nested identities shaped by these small-scale settings (as described for instance by Di Carlo (2011) for the Lower Fungom area in Northwestern Cameroon, Storch et al. (2014) for Nigerian case studies, Moore (2004) for the Mandara mountains of Northern Cameroon, and Lüpke (forthcoming b; 2016a) and Quint (forthcoming (2017) for Baïnounk groups in Southern Senegal). In Australia (Singer \& Harris forthcoming) and North America (Thomason 2016), formerly multilingual societies have already been affected so drastically by violent colonial interventions that only traces of their linguistic ecologies remain and indigenous identities are now distilled in the few remaining languages, opposed to the colonial languages. On the African continent, beginning research on smallscale multilingualism is already revealing how widespread these settings are and how important they are for continuing linguistic diversity (Di Carlo et al. 2016). Lüpke (forthcoming d) argues that it is exactly the existence of these small-scale multilingual societies that makes African language ecologies vibrant.

\subsection{Whose heritage, whose loss?}

It seems to be an unavoidable side effect of accelerating globalization that culture is increasingly reframed as heritage (Berliner forthcoming; Brumann \& Berliner 2016), and language is the most recent addition to the imaginary body of universal heritage, as testified by the listing of the $\mathrm{DoBeS}^{6}$ archive of endangered language corpora in the UNESCO register of intangible heritage. A vehement critique of LDD as preserving heritage is put forward by Deumert \& Storch (forthcoming), strongly echoing critical points made before (e.g., Canut 2010; Duchêne \& Heller 2007; Woodbury 2005). For Deumert $\&$ Storch, LDD is firmly inscribed into the colonial episteme of knowledge extraction purported through

\footnotetext{
${ }^{3}$ But see Connell (2015) for a discussion of situations in which colonial languages are targets of language shift.

${ }^{4}$ There is a growing awareness within contact linguistics of the need to study the "societies of intimates" in which most multilingualism and language contact is situated (Trudgill 2011).

${ }^{5}$ See Barbieri et al. (2012) for a genetic study that shows how widespread female mobility is in West Africa. The linguistic repercussions of this finding for theories of multilingualism and language contact remain largely unexplored.

${ }^{6}$ DoBeS stands for "Dokumentation bedrohter Sprachen" 'documentation of endangered languages', an influential grant programme of the German VW Foundation.
} 
continuing unequal North-South relations ${ }^{7}$ and serving the career needs of Northern academics at neoliberal universities through external affirmation of their data as heritage, but is based on a wrong idea of language and disconnected from everyday practices of speakers and inaccessible to them.

Many of the concerns voiced by Deumert \& Storch pertain to LDD practices encapsulating the "ancestral code" model:

Documentation of the ancestral code, like the endangerment construct itself, can be termed, without any intention to disparage (see Williams 1973) as nostalgic, in the sense that it selects as important from among all the speech in a community that speech which gives evidence of a feature of the past which may not persist long into the future, namely the ancestral code [...]. On the academic side, we may see linguistic reconstruction, or a focus on the most traditional variant forms, as nostalgic tendencies, while purism and assertions of the linguistic code as intrinsic to ethnic or spiritual identity or to traditionalism are forms of nostalgia in the popular sense. (Woodbury 2011: 178)

The ancestral code model is only one model of $\mathrm{LDD}^{8}$, albeit a very influential one that is problematic when employed unreflectedly by LDD practitioners ${ }^{9}$. This model and its critique raise important questions about the language-as-heritage construct: Whose sense of loss frames LDD and LEL research - that of the linguist or that of the speakers? From the scarce existing research on the interactions of speakers of small African languages with LEL discourses it emerges that even when they engage with it, as in the case of the Tima (Dimmendaal 2015) or the Baïnounk (Lüpke forthcoming b; Lüpke 2016a), it is to create and assert symbolic identities on the national plane rather than to reinvigorate linguistic and cultural practice at the local level. This process of "strategic essentialism" (Spivak 1990) expressed through the symbolic, not the practical value of products of LDD research such as corpora, grammars and dictionaries (which do not need to be used or usable to fulfil their purpose, because their very existence suffices for making a language visible) is often not what linguists have in mind as an outcome of their research. Anecdotal observations that language shift is not perceived as traumatic by speakers in the ideological home bases of these languages (see 2.2), but mainly felt as a loss by Diaspora speakers and organizations, abound. It may be argued that in these instances, the lack of nostalgia is linked to the fact that the loss has not yet happened in the places associated with these languages. Indeed, many LDD projects in African settings are presented as pre-emptive measures to prevent such a loss and, should it happen, to preserve a record of the ancestral code. Extracting data for the Northern good while assuming a patronizing stance that pretends it is also for the natives' benefit can indeed be regarded as an expression of colonial thinking and of the white saviour complex. But are Northerners allowed to be

\footnotetext{
${ }^{7}$ As supporting evidence for this argument they quote the geographical distribution of DoBeS projects, of which only 3 were located in Europe. Rather than being a consequence of the coloniality of LEL research, the concentration of this research on places in the global South can also be explained with the fact that the linguistic diversity of Europe has been dramatically depleted through standardization and formation of monolingual nation states, whereas it has not affected linguistic diversity in Africa, Southern America and Melanesia to the same extent. Rather than being causally related to a colonial episteme based on Northern experts extracting knowledge from exoticised places (the "field"), the location of many LDD projects in the global South is correlated with the high linguistic diversity found there.

${ }^{8}$ See Himmelmann (1998), Woodbury $(2003 ; 2011)$ and Grinevald \& Sinha (2016) for detailed accounts and critical discussions of models of LDD.

${ }^{9}$ It is important to differentiate here between LDD research that focuses on particular registers seen as threatened, often independently of the vitality of the target language, for instance secret languages, healer discourse, linguistic practices during initiation and mourning ceremonies, and on research aiming at presenting a documentation of a target language. The former can be seen as an instance of the ancestral code model that nevertheless documents some registers of synchronic language use. The latter, when exclusively bound to this model, cannot capture the fullness of contemporary linguistic practice.
} 
concerned about African linguistic and cultural heritage at all? ${ }^{10}$ And, independently of the appropriateness of global claims on local heritage, is empiricism - a desire to describe and document, not to save - always epistemic violence? Current critical heritage studies concentrates on "a denunciation of the politically powerful $[\ldots]$ and a valorisation of localism" (Berliner forthcoming). With Berliner, I would like to argue that justified preoccupations with power imbalances and the constructedness of social categories such as heritage and language, important as they are, should not prevent us from continuing "our endeavour to account for "'the human experience", i.e. to understand and explain the mechanisms through which humans live, albeit in diverse cultural settings" (Berliner forthcoming: 1f.). ${ }^{11}$ Mbembe (ms.) lucidly calls for "pluriversity", that is, a breaking of academic practice with the hegemony of Northern traditions of knowledge production and openness to new interpretive frames. In the case of LDD and LEL research such new frames might include through which processes and by whom language is construed as threatened heritage, and how the heritage perspectives of Northern experts and local agents differ, or how the condensation of linguistic practice into an 'invented tradition' (Ranger 1983) interacts with its continuing use.

What is asked for, then, is a critical engagement with, rather than an uncritical adoption of the languageas-heritage stance. An unreflected "ancestral code" model often puts LEL research at odds with another explicit goal of this research: the documentation of actual language use, as set out in Himmelmann's exemplary research paradigm (Himmelmann 1998). Where language change and shift is always perceived as attrition and death, linguistic purism (Dorian 1989) and linguistic nostalgia (Woodbury 2005), affect both speakers and linguists. Self-censorship of speakers and an elimination of certain genres, speech styles and speakers from the documentary corpus is the consequence. Marten \& Petzell (2016) provide an enlightening case study on 'purification' through editing within a language documentation project and argue compellingly for an inclusion of all versions of texts as authentic. They call for studying the editing process as an integral part of the research. Where such care and reflexivity are not applied, the research community is robbed of exactly those empirical data needed to study the consequences of code interaction, variation within and across speakers and places and generational language change necessary not only for understanding language change but also for more representative accounts of actual language use. That the idea of language-as-heritage is ideologically charged can be illustrated by disputes on authentic forms of language that result in contradictory endangerment assessments for African languages: major languages such as Wolof that can be construed as the "winners" in terms of language vitality according to mainstream criteria such as expansion into new domains and growing speaker numbers are at the same time perceived as endangered by their very success, through decreasing lexicogrammatical complexity and by losing purity and heritage appeal (Lüpke 2010b; Mc Laughlin 2015). How language can become a carrier of claims of indigeneity, authochthony and heritage, and which incarnations of language are seen as the most apt in fulfilling this function are therefore important areas for LEL research. Selecting particular languages and particular forms of discourse and construing them a priori as reflecting a group's heritage is a continuation of colonial perceptive pitfalls and puts LEL research into the danger of being instrumentalized by nationalistic, sometimes even chauvinistic, goals of political stakeholders.

2. Objects and ontologies of language documentation and description

\footnotetext{
${ }^{10}$ Nostalgia is a professional preoccupation not confined to documentary linguistics, but shared with anthropology, see Berliner (2014).

${ }^{11}$ Grinevald \& Sinha (2016) investigate LDD and LEL research in the light of unequal North-South relations, focussing on South American settings. They criticize models of LDD that are based on description + technology + revitalization and draw attention to the need of reflective and interdisciplinary practice, but do not reject LDD as a valid enterprise altogether.
} 
Descriptive linguistic research, in particular on the African continent, is tied with colonization and continues a tradition that draws heavily on Northern artefactual language epistemes (Blommaert 2008; Lüpke \& Storch 2013). These nationalist monolingual ideologies had their heyday in the late $19^{\text {th }}$ century, which marks the beginning of descriptive research on African languages as part of the colonial enterprise. Core concepts of LDD such as 'language', 'speech community' or 'ethnolinguistic group' have since then been dismantled by sociologists, sociolinguists, anthropological linguists, anthropologists and historians for being constructs that lack epistemological validity and for naively continuing a colonial tradition. LDD is at the interface of different linguistic disciplines, which provides an opportunity for a rethinking of many of its ontologies by taking inspiration from the critique of these basic concepts that are still widely unquestioned by many LDD practitioners.

\subsection{Language and languaging}

Although the question of what constitutes a language (and what a dialect) is not a linguistic one, since named languages come into existence as imaginary objects through socio-political motivations, descriptive linguists often treat these constructs as if they were objects of the real world. Different glossonyms present different viewpoints on what constitutes a language and can offer insights into the formation of these viewpoints (see also 2.2. below) Pace Haspelmath (forthcoming (2017)), language names should therefore not be harmonized and unified. Rather, the variety of glossonyms and their extensions and intensions must constitute a subject of research in their own right. So far, the focus of much LEL research has been on the documentation and description of named languages, often based on pseudo-scientific standardized catalogues such as the Ethnologue (Simons \& Fenning 2017), which lists languages and identifies each of them with an ISO code, a process that sanctions the prevailing positivistic view of languages.

Cysouw \& Good (2013) have drawn attention to the process of reification that underlies linguistic description by coining terms that reflect the artificial (as opposed to scientific) nature of the process and the artefactual nature of the resulting objects - languoids, as expressed in different snapshots or doculects. Languages (just as dialects and ideolects) as fixed and discrete linguistic objects come into existence through linguistic description that presents only a vignette of linguistic behaviour that in reality is variable within and between speakers and over time. Our prevalent practice of capturing this variation as between distinct variants is owned to tradition, not to observational or descriptive adequacy: it is well known within our discipline that there are no dialects, because sets of isoglosses are not coextensive; that boundaries between languages are geopolitical demarcations exacerbated by state borders but not applicable in practice; and that speakers express rich social meaning through variation, not just between different speakers and places, but also within an individual's language use. Languages are therefore always sites of ideological contestation. Language ideologies (Irvine \& Gal 2000; Kroskrity 2007) - the set of beliefs about language, whom it represents and by whom and how it should be used - often differ markedly from actual language use, and not only speakers themselves, but also language researchers carry their own beliefs that can shape their perceptions and interactions (Labov's famous “observer's paradox). Ngué Um (2015) offers an insightful discussion on how the linguist's idea of language can clash with multilingual language use in a Cameroonian language ecology. An exclusive concentration on named languages is problematic for LDD, both from an empirical and epistemological viewpoint, even if, as I do, one regards the language construct as an important heuristic and does not want to discard it (see 2.1 below). It is not good practice to start out with a glossonym for initial LDD research and expect a clear entity representing this glossonym to emerge from language use. On the other hand, glossonyms are not just an invention of linguists: languages, registers and ways of speaking can be named by speakers and outsiders, so this process of reification must have psychological salience and social relevance. What is important is a recognition of the multiple ways in which 
individuals can maintain multiple identities through associated language names which do not refer to mutually co-extensive representations, but each pick out different traits of identity. This needs to be flanked with an awareness that we need to distinguish at least two distinct but interconnected levels at which representations of language are created: a level of social identity and a level of linguistic representation. Studying linguistic ideologies and how they contribute to the crystallisation of aspects of identity in language names is an important area of LDD and LEL research and important prerequisite to linguistic description and documentation.

Descriptive linguists often skirt the epistemological question of how variable language use can be reified into a language construct by working only with a very limited number of consultants and a small text corpus. Current sociolinguistic research conversely often only focuses on contexts putting the validity of the language construct into question, but at the same using language names as a convenient reference point. These inconsistencies are in particular true for multilingualism research, and therefore relevant for LDD in Africa, where multilingualism prevails. Recent research has drawn attention to the importance of practices that transcend language boundaries in multilingual speech, moving away from ontologies that see its constituent parts as unambiguously consisting of different languages. Rather than committing to a language-based view on code interaction as testified by established terms such as 'code switching' and 'code mixing", recent work describes it in terms of 'languaging' (for instance Mignolo 1996), or 'translanguaging' (García \& Wei 2014). It is not clear how this research handles the contradiction created by the fact that in its works, languages are still named, and languaging is described through naming the languages participating in it, although they have been dismissed as invalid. A more holistic approach lies in a theoretical reflection on the nature and scope of reification, and on the study of the interaction of language and languaging, as discussed in 2.1. Research on African multilingualism can contribute to a nuanced investigation of language boundaries and their transgression. Ongoing corpus-based studies show that boundaries between languages can be more or less accentuated in different registers, genres, or for different speakers, and fused forms are not ubiquitous in all discourse contexts (Cobbinah et al. 2016). Pragmatically governed situational contexts require different parts of speakers' repertoires to be active or inactive, resulting in different cognitive constraints on language use in them (Green \& Abutalebi 2013), and therefore creating contexts where languages are kept apart and contexts in which they are dissolving. Counter prominent predictions that intensity of contact phenomena increases with intensity of language contact, it is not always the case that codes are most monolingual and separated (as in code switching) in the most monolingual language situational contexts, and most fused in the most multilingual ones (Lüpke in preparation). It follows that looking at how language and languaging are manifested in different situational contexts is highly relevant for more accurate linguistic description and empirically grounded contact and multilingualism research. The different theoretical perspectives on multilingualism are therefore not mutually incompatible but applicable to different types of texts as soon as one looks at a wider range of multilingual speech than normally sampled.

As a consequence, it needs to be a core concern for LDD research to develop a paradigm that privileges neither languages nor repertoires a priori but one that provides rich and varied data on linguistic practice offering an empirical foundation for the study of variation and for the reification process so central for linguistic description and imaginations of speech. To this end, we need rich data sets and empirically grounded models of capturing variable and shared parts of repertoires. Here, LDD has a central role to play, since for the first time in the history of modern descriptive linguistics, this subdiscipline has as its core the creation of large corpora of language use for small languages. These corpora can provide an excellent data base for studying the extent and limits of variation, provided they present a diverse sample of language use. Such corpora make it possible to investigate speakers' linguistic behaviour in space 
and time and detect features that are more or less prone to variation. A comparative examination of such features can be theorized as corresponding to this speaker's prototypical language use (Rosch 1973); for the adaptation of prototype theory to conceptualizing variation in multilingual corpus data by Rachel Watson see Cobbinah et al. (2016) and Watson (in preparation). Both the stable core and the extent of variation can be represented in a Venn diagram, as in Figure 1 below, which shows the variation and core emerging from the speech of three speakers:

Figure 1: Schematic representation of language prototypes for three speakers (translated from Cobbinah et al. 2016)
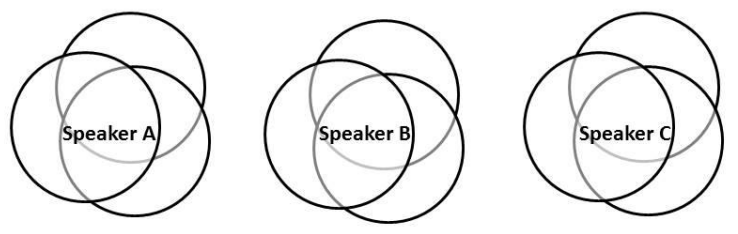

Several speakers will not share identical lexicogrammatical features in their core. By superposing their prototypes, a yet smaller core that can be conceptualized as a language emerges, illustrated by the central part of the Venn diagram in Figure 2.

Figure 2: Schematic representation of the prototype emerging from the shared core of speakers (translated from Cobbinah et al. 2016)

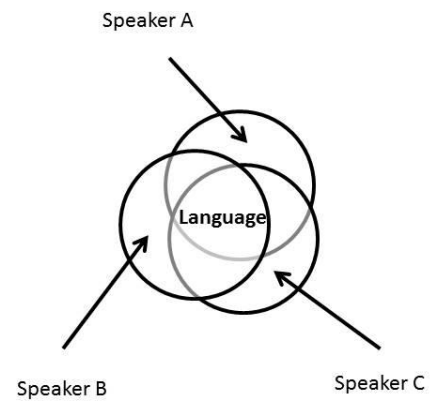


In analogy, that dialects and related languages share a number of features can also be visualized through mapping their shared cores together in a Venn diagram:

Figure 3: Schematic representation of the convergences and divergences between languages (translated from Cobbinah et al 2016):

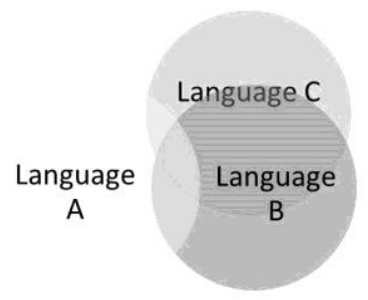

Depending on which speakers, texts, and features are selected, and whose metalinguistic knowledge and perspective is applied, different prototypes emerge. Language prototypes allow visualizing language use as shaped by two simultaneous opposed forces. The first force is one of convergence and unification, resulting in a conventionalized core. The second force is one of divergence, produced through the frequency of particular patterns in an individual's changeable social network and through innovation. This force is represented in the areas of the Venn diagrams above that do not overlap. The areas of variation are also those where particular features can acquire social meaning (or become socalled second order indexes, see Silverstein 2003). Through a dynamic process of language change, convergent and divergent parts of a repertoire are constantly shifting, mitigated by pragmatic constraints circumscribing the social conditions of language use in a given language ecology. By not eliminating variation but making them a subject of research, LDD corpora can therefore also contribute to the study of social dimensions of language use.

\subsection{Language and land}

Languages come with territories, imaginary home bases that host speech communities and produce native speakers. Yet, just as we have to understand concepts of language as social constructions and linguistic abstractions, we need to distance ourselves from naively using concepts such as 'speech community', and 'ethnolinguistic group', and from the idea that there exist spaces that are, have been or should be linguistically homogenous. Territorialising a language is an ideological process (Blommaert 2010). Within the LEL programme, the idea that one language can exclusively express the linguistic and cultural identity of a space and its inhabitants prevails. ${ }^{12}$ Such a view reflects European nationalist language ideologies, culminating in the idea of the monolingual nation state and the monolingual native speaker inhabiting it and who crucially can never have more than one mother tongue (Bonfiglio 2010), which themselves reduce the complex linguistic realities of nation states. This essentialist or categorical view of identity contrasts with the relational, multifaceted ethnolinguistic identities common on the African continent. In fact, the trend to see named languages as exclusive indexes of ethnic identity is strongly associated with colonization, as is the creation of the concept of ethnic group itself (cf. Amselle 1990; Lentz 1995). As is the existence of languages as discrete objects,

\footnotetext{
${ }^{12}$ Incidentally, this view is reflected in the name of the most widely used language catalogue - the Ethnologue.
} 
the existence of ethnic groups is a question of ontology that is intimately linked to our epistemologies and methods. Who we are, which questions we ask and why, who we ask, and whether we make a distinction between discursive and metadiscursive practices, will frame our answers, that often go hand in hand with a process of iconization and erasure (Irvine \& Gal 2000): members of a category seen as particularly salient and prototypical according to our predetermined standpoint will be highlighted and come to represent the constructed concept (read here as language or ethnic group) as a whole; members who seem to fit less will be erased from our ideological representation of it. There is an urgent need for a deeper awareness of this process, because in the LEL context, it is at work twice: essentialist identity concepts frame LVE catalogues and therefore linguists' expectation on what a language will look like. Speakers' representations on group constituencies are likewise shaped by language ideologies that erase the practices of many people locally present, for instance of in-married women, descendants of slaves, or fostered children, and the two may feed into each other, creating a vicious circle. In many African patrilineal and virilocal societies, languages are construed as the "patrimonial languages" of a place based on the remembered language of its male founder and his (in contexts of exogyny) predominantly male descendants. Its real linguistic diversity thus becomes invisible, since most of its inhabitants are excluded from representing it. Figure 4 illustrates the outcome of this process for the inhabitants of a village in Casamance.

Figure 4: Schematic representation of those inhabitants of Agnack that are iconized and erased from representing the village as "Baïnounk"

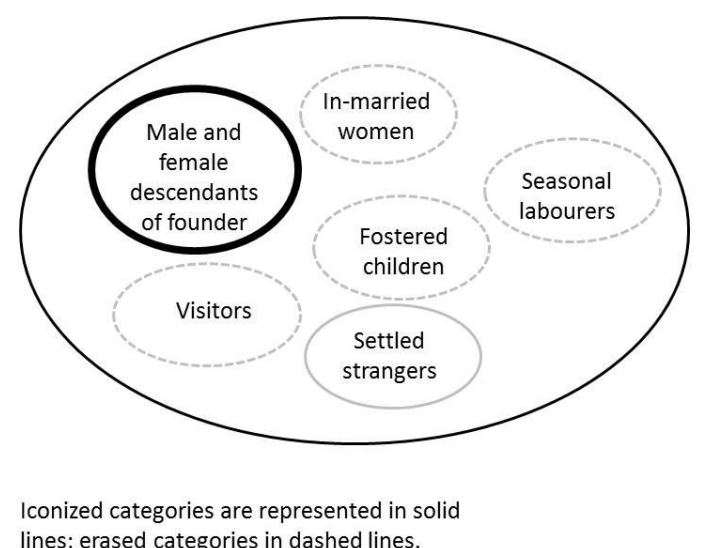

In the light of this diversity is therefore extremely harmful when recommendations for initial LDD in Africa suggest focusing on formally educated men (as done by Mcgill \& Austin 2012), since this drastically skews its data base and normalizes an imaginary homogeneous speech community that does not exist. It is shocking that the very research paradigm aiming at describing and documenting linguistic diversity is only able to do so when eradicating diversity in its data. ${ }^{13}$ The speech community is a concept that has been undone by sociolinguistic research, starting with Gumperz (1962), and has since been replaced with concepts that capture the multi-layered nature of interaction in any setting. Influential is the notion of community of practice (Wenger 2000), which designates smaller sites of

\footnotetext{
${ }^{13}$ It should be noted that in addition to continuing colonial knowledge extraction practice, since the conditions of data collection are controlled by the researcher, working exclusively with male research participants also testifies of a sexist bias.
} 
social practice at the micro level that create their own sets of conventions: church congregations, parentteacher associations, or generations of initiates... Another way of looking at changeable linguistic practice in a given location is to investigate language use in the social networks of individuals (Milroy 1980), pioneered for African contexts by Beyer (2010) and Schreiber (2009).

Ideologies do not only frame how we define a category and its members, they also influence its scales, i.e. which contrasts we assume between categories. Different perspectives (as men, women, Europeans, outsiders, elders, shrine holders ...) result in different categorizations of varying granularity, and often lacking referentiality. The label Baïnounk, for instance, is only a meaningful category when contrasted with non-Baïnounk, but does not give rise to any internal homogeneity in cultural and linguistic behaviour. The famed Dogon are a group so designated by their neighbours, but speak 29 related languages and lects plus an isolate and have no shared cosmology or cultural canon (van Beek et al. 1991), despite popular imaginations to the contrary, nor do they express an overarching shared identity reflected in an endoethno- or glossonym (www.dogonlanguages.org). Ethnic groups and named languages that can be put on a map do exist; but as idealized representations whose essence depends on perspective, not as objects of the real world. It is important for LEL research to recognize the ideological nature of the categories of speech community and ethnolinguistic group, since otherwise a real appreciation of the constituency and linguistic practice of a place is blocked, with dangerous consequences in particular for LVE judgements. It is equally important to document how these representations are formed and changed over time.

\section{Sites of vitality}

How the Eurocentric expectation of a monolingual ethnolinguistic group is turned on its head by African realities is best illustrated with a look at African sites of high linguistic diversity. Regions characterised by high numbers of small languages are concentrated in the sub-Saharan fragmentation belt, reaching from the Atlantic coast of West Africa to the Ethiopian escarpment (Güldemann 2008). A high degree of linguistic diversity as present particularly in this area of Africa is associated with a high number of named languages attested there. These languages are not spoken by small, isolated tribes, but by smallscale multilingual groups who exceedingly also participate in larger-scale networks and speak larger languages. An understanding of how and why languages thrive in these areas is linked to a shift away from seeing multilingualism as a modern and globalized phenomenon to a longstanding African reality. Before discussing small-scale multilingualism in 3.2, I therefore discuss how multilingualism is viewed in mainstream LVE catalogues and what different perspectives emerge from a closer study of African multilingual situations.

\subsection{Multilingualism as the African normality}

UNESCO has recognized the multilingual nature of many global contexts and promotes inclusive multilingual education for Africa (UNESCO 2016). It must be interpreted as a transfer from diglossic, conflictual, multilingual situations (or perspectives on multilingualism that see all multilingual situations as situations of competition) that its LVE catalogue insists so much on criteria associated with monolingualism or monolingual ideas of multilingualism (Auer 2007; Piller 2016). Monolingual language ideologies continue to shape prevailing perspectives on not just the African situation. But especially since Africa hosts a high proportion of the world's languages in settings that defy these ideologies, it is of prime importance to develop viewpoints that allow a better characterization of vitality and endangerment on this continent. An acknowledgement and better understanding of multilingualism must constitute a central component of this endeavour, since most Africans live in multilingual 
situations the diversity of which remains understudied in large parts (Di Carlo et al. 2016; Juillard 2005; Lüpke 2010a).

"Multilingualism is the African lingua franca" (Fardon \& Furniss 1994: 4). The populations of some small monolingual areas on the African continent may be close to a prototypical monolingual ethnolinguistic group, for instance parts of the territory associated with the Datooga (Mitchell, p.c.). Yet, by far the most African languages are spoken in multilingual contexts; a homogeneous speech community must therefore be seen as an exception. It is common to frame multilingualism as di- or triglossic: official languages occupy the top level; regional languages at mid-level; and local languages are seen as occupying the lowest level of a hierarchy based on reach, prestige and access to resources (Swaan 2001). It is also common to see multilingualism as a recent phenomenon linked to the introduction of colonial languages and to growing rates of migration. Yet, a growing body of research, summarized in Di Carlo et al. (2016) for Africa, and in Lüpke (2016b) worldwide, points to the longstanding existence of multilingualism in places not commonly imagined as multilingual, and through motivations that are not polyglossic, i.e. not based on domain specializations for and hierarchical relationships between languages. For many rural groups, untested expectations that they were monolingual constitute ideologically framed judgements that have hindered a real assessment of their language use, until very recently. Such assumptions are underpinned by mainstream imaginations of multilingualism according to which it constitutes a new and urban phenomenon, for instance in the "superdiversity" discourse (Blommaert \& Rampton 2011), which exclusively associates intense multilingualism with modern, globalized contexts, and by a dominance of studies of urban multilingual settings globally and in Africa. This discourse is flanked by the still dominant characterization of precolonial African groups as "tribal" in the popular mind, picturing them as homogeneous and sedentary groups. The opposite is true: as argued in 2.2 above, the "tribal" model of fixed ethnolinguistic groups spoken by was introduced by colonial activities. Colonial and postcolonial classifications imposing essentialist identities and strict boundaries on groups that were and are in many cases based on multiple relational identities rather on one exclusive and fixed ethnolinguistic identity, need to be replaced by studies overcoming these biases.

If we accept multilingualism as the African norm, it is much more promising to abandon the notion of a homogeneous speech community and assess LVE based on language ecologies, the coexistence of diverse repertoires nurtured by their social function in a home base that can be a ward, village, polity, town, or city, or state. The recognition of meaningful geographical settings and social spaces can then be based on social contexts for interaction defined by the networks and trajectories of individuals. Social spaces are thus not mutually exclusive but multiple, nested and changing, just as the situations and networks in which their participants use their repertoires.

\subsection{Small-scale multilingual societies as hosts of vitality, not endangerment}

Among the social spaces that host vibrant language ecologies in Africa, it is not urban configurations, but small-scale rural multilingual societies that must occupy a prime position ${ }^{14}$. Diversity on this continent is directly associated with small groups whose members are bi- and multilingual in small languages (Dimmendaal 2008). Yet, low speaker numbers and bi- or multilingualism remain strongly associated with LEL, despite the incongruity of this assumption for situations of still thriving diversity. Diversity entails the existence of small language communities whose members often engage in

\footnotetext{
${ }^{14}$ See Lüpke (2016b) for a definition and case studies of small-scale multilingualism.
} 
extensive social exchange. Therefore, we also need to recognize that bi- and multilingualism in these communities is not always an indicator of on-going language shift and linguistic oppression, leading to LEL. In contrast, a setting that nurtures small-scale multilingualism constitutes the most supportive environment for small languages, since it allows their speakers to communicate within their wider environment while also providing contexts for using those parts of the repertoire only shared among smaller communities of practice. It follows that interdisciplinary, sociolinguistically and anthropologically informed perspectives (Childs, Good, and Mitchell 2014) on meaningful geographical areas and their language ecologies that sustain complex linguistic repertoires (Mufwene forthcoming, 2016) are more apt at gaining empirically sound assessments of their synchronic vitality than a focus on individual languages. There is a growing body of research on this type of rural, smallscale multilingualism, investigating its sociohistorical motivations and patterns of multilingual language use. Among the social exchanges that nurture multilingualism in these settings, Lüpke \& Storch (2013: 33) highlight the following as particularly relevant for African contexts:

- Exogamous marriage patterns, sometimes culminating in systematic linguistic exogamy

- Language acquisition in peer groups and age classes, not in the nuclear family

- Widespread child fostering irrespective of language borders

- Mobility and migration for ritual, religious, economic and educational purposes

- Joking relationships and patronymic equivalences beyond ethnolinguistic boundaries

- Polylectality and multilingualism for occupational, hierarchical, ritual, and religious functions

- Writing practices relying on conventionalised exo- and multigraphia

Since LEL research makes predictions about the likely future of a group's linguistic behaviour, albeit only assuming the most pessimistic teleological perspective, detailed accounts of current language socialization and language use, including multilingual practices, (wherever possible complemented by diachronic data and historical information), must be seen as an essential prerequisite of this endeavour. In the light of the scarcity of historical data for most African situations, sound sociolinguistic and anthropologically and historically informed linguistic research on present-day settings is of prime importance, as it allows inferring possible historical scenarios from types of contemporary social and linguistic interaction. LEL research funding has enabled a dramatic increase in field-based empirical linguistic research. Nevertheless, it is a deplorable requirement of this funding that languages need to be proven to be endangered in order to be eligible for funding prior to their detailed documentation and description. This requirement hinders detailed sociolinguistic research and leads to endangerment judgements that are merely contended rather than empirically verified. Only a dramatic increase in interdisciplinary linguistic research on language ecologies, including small-scale linguistic settings, can redeem this dissatisfying situation. Lüpke (2015) has identified the following factors for assessing the vitality of African linguistic ecologies:

- The existence of communities of practice and social networks for language socialization in a given language ecology

- A home base providing the opportunities for maintaining and creating communities of practice and social networks in a given language ecology

- Socioeconomic and political stability in the language ecology in question;

- Attitudes by speakers and non-speakers to the language ecology

- The reification of languages in the ecology as 'named languages'

External factors resulting in displacement or eradication of its members play a prominent role in destabilizing language ecologies, due to their small size. Positive attitudes towards multilingualism, i.e. 
the make-up of the entire language ecology, not just individual target languages, are crucial. While reification of individual languages means that important symbolic functions can be associated with their use, well-intentioned interventions commonly described as language revitalization ${ }^{15}$ aiming at turning imaginary ancestral languages into real objects can be very harmful, especially if inscribed into a monolingual language development model. To give but one example, the expectation for a thriving language to expand into new domains and increase numbers of speakers must have a detrimental impact on other languages used in the ecology, and on the intricate balance of social interactions in them. Rather than empowering small-scale ecologies, such activities, through their selective character, create linguistic exclusion.

\section{Sites of exclusion}

The most dramatic linguistic exclusion on the African continent pitches all indigenous languages, regardless of their size, against the colonial ones. The cultural, political and socioeconomic capital attributed to colonial vs. to all other languages on the African continent, and the image of languagehood projected by colonial languages disadvantages all indigenous languages, irrespective of their size and prestige. As such, the presence of languages of colonial provenance, and their strong association with European nationalist language ideologies based on standardization and monolingualism, or out-dated models of bilingualism conceptualizing it as "two language solitudes" (Cummins 2008) is indeed threatening all other languages. With its current focus on minority languages, the LEL model, aimed at strengthening moribund minority languages through massive interventions (see Blench 2007; Connell 2007; Dimmendaal \& Voeltz 2007 for surveys of such language situations in Africa), is therefore not the most helpful one to overcome the continued marginalization of the majority of African indigenous languages. This marginalization affects big and small, majority and minority languages in the same fashion. It is therefore not surprising that a frequent trope depicts large African languages such as Wolof, Yoruba, or Chichewa, elsewhere described as "killer" languages (Batibo 2005) as endangered (for instance Yoruba in the Premium Times Nigeria, October 4 2015). In addition to their heritage value, which can be decreased by their function as languages of wider communication, as discussed in 1.4, their position is ambivalent in the sense that they can be targets of language shift, without ever corresponding to the image of a language used in all domains, in speech and writing, that is given off by endangerment catalogues and powerful Northern language ideologies alike. The monopoly of official languages in education and formal contexts, and the blueprint their use provides for conceptualizations of language marginalize African languages not just in terms of their status, but also in terms of blocking the development of alternative models of language development inspired by indigenous communication patterns, with the effect of creating a domino-like pattern of exclusion: since languages need to be standardized in order to acquire the status of a written language, their non-written variants become relegated to the status of unwritten vernaculars (Blommaert 2006; Martin-Jones et al. 2011). As soon as one of these vernaculars has elevated its status to the status of a written language, all others need to follow suit, leading to an atomization of standard languages that have very little real scope to be used but are of huge symbolic significance in the standard language market place. It is worthwhile reflecting on the role of linguists in perpetuating this powerful Northern standard language culture that relies on writing as the prime insignium of languagehood, as its focus on writing is mirrored by the graphocentrism of linguistics as a discipline. Although for more than a century we have been able to record speech, and although there have a growing number of audiovisual data available,

\footnotetext{
${ }^{15}$ Language revitalization, although often seen as an integral part of LDD and LEL research, is not treated in detail here. The reader is referred to the recent critical overviews of language revitalization from an Africanist perspective in Childs (forthcoming 2017), Lüpke forthcoming 2017) and Sands (forthcoming). See also Newman (2003) for an influential critique of this endeavour.
} 
linguistic analysis is almost exclusively confined to working with written, often standardized, transcriptions of these data. This preoccupation with language as a visual entity translates to the almost automatic reflex to see transcription as an initial step towards the creation of a practical orthography for an unwritten language (Schultze-Berndt 2006), which is very often seen as the corner stone of language development for minority languages. Yet, the assumption that orthography development is part and parcel of LDD and essentially a technical task (Seifart 2006) has been questioned by a growing number of Africanists (Ameka 2015; Essegbey 2015; Lüpke, 2004, 2011, forthcoming a), because it cements exclusion. Which speakers of a small-scale multilingual society will invest in reading and writing one or several of the languages in their repertoires, languages that are shared with only several hundred others? Who will train the teachers and provide the written environment needed to support the use of these languages in writing? What happens to the acquired literacy skills when individuals migrate and find themselves in a completely different linguistic environment? The richest nations in the world struggle with the task to produce multilingual readers and writers in the monolingual model of multilingualism. There is no good reason to assume that this paradigm will contribute to the empowerment and revitalization of small African languages beyond the symbolic value of turning them into languages that can be written.

\title{
5. The future of LDD and LEL research in Africa
}

How can we discover new perspectives for linguistic research that are ethical and grounded in locally anchored epistemes, yet of cross-linguistic relevance? From an Americanist perspective, Grinevald \& Sinha (2016) chart the task facing us as follows, reminding us that LDD is much more than a set of technologically facilitated activities resulting in the creation of a language archive:

\begin{abstract}
Although we do consider the dissemination throughout the research community (including indigenous researchers) of knowledge and skill in using up-to-date technology for recording, annotation, description and archiving of data to be of great importance, we would also argue that this should be complemented by the dissemination of an understanding of the relevant methodological and ethical principles of qualitative research and of research in indigenous cultures. We would therefore advocate that just as much attention is paid, in ELDR [Endangered Languages Documentation and Revitalization] education and training, to the sociocultural context and dimension of ELDR as to its linguistic-theoretical and technical aspects. ELDR is, or should be, an interdisciplinary activity, and its theory, education and practice should reflect this. The theory, methodology and practice of ELDR needs to be informed as much by the reflexive and qualitative stance of disciplines such as anthropology, as by the experimentalist and quantitative stance of disciplines such as cognitive psychology or corpus linguistics. ELDR education and training should reflect the dynamics and complexities of knowledge as practice/practice as knowledge, only part of which is knowledge of how to use technical equipment and software tools. (Grinevald \& Sinha 2016: 40f.)
\end{abstract}

For Africa, this reflexive stance needs to lead us away from Northern conceptualizations of knowledge and practice. African interactional practice has remained largely unscathed by colonization. If we stop wanting to see language use and language development conforming to Northern models and 
expectations, we will be able to uncover sites of resilience and creativity, just as in this graffiti, on the wall of the former hotel swimming pool that otherwise clearly is a failed development project:

Figure 5: Grafitti in the grounds of an abandoned hotel in Kabrousse, Casamance

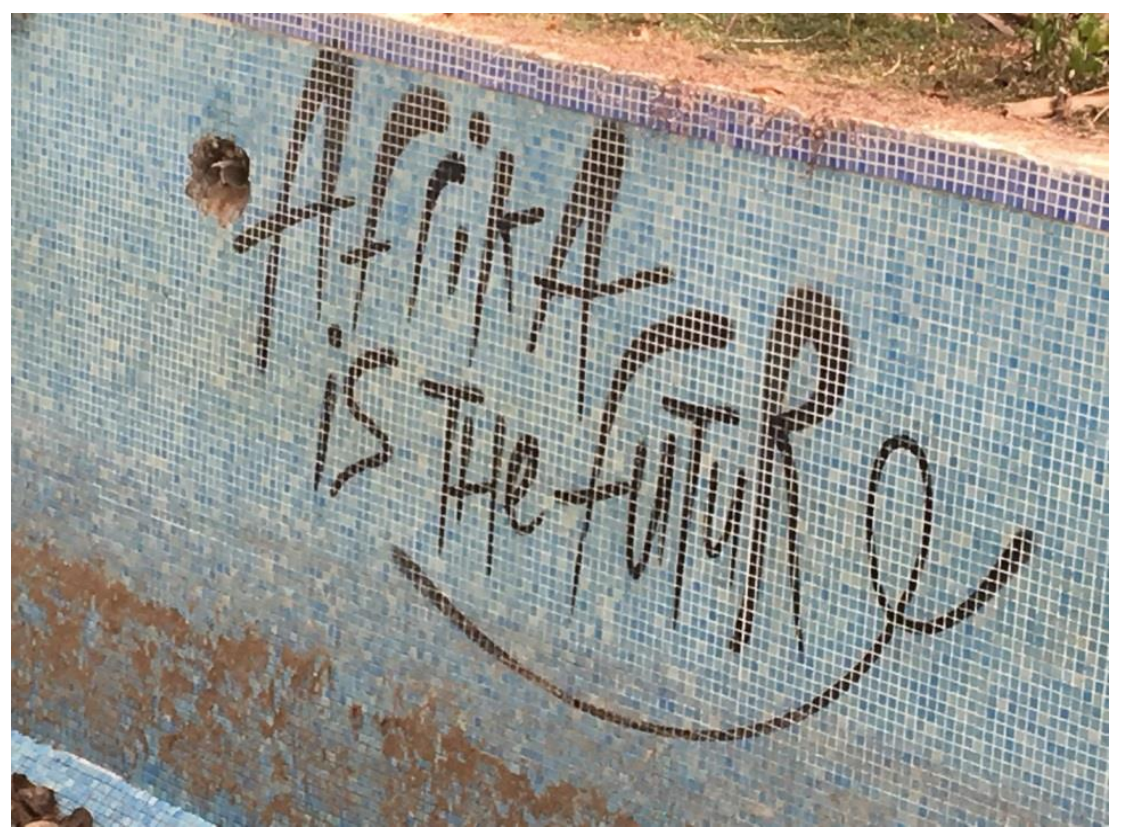

Translated into concrete avenues and methods for future research, such a shift in perspective could entail recording and analysing social interactions (Dingemanse 2011; Lüpke 2016a). Corpora of situated language use could include not just a rich set of spoken language data, but new forms of communication in digital media, to provide more data on smaller languages to the study of digital communication in African languages (Deumert 2014; Deumert \& Lexander 2013). Grassroots literacy could be included in the scope of LDD projects, as the way in which (and which!) languages are used in a particular setting offers alternative imaginations of what multilingual writing cultures might look like (Asfaha \& Juffermans 2014; Juffermans 2015; Lüpke forthcoming a). A perspective that acknowledges people as agents in their sociocultural environment who exert choices (Dimmendaal 2015) and adapt to changing circumstances (Mufwene 2016) is a less patronizing position than an outlook on people as condemned speakers of an endangered language. Studying these ecologies with an interest in how existing practices nurture multilingualism and social cohesion and might be harnessed for development (including multilingualism management in the North) is much more promising than insisting on top-down, onesize-fits-all models of language development (aptly criticized by Rohloff \& Henderson 2015; Wolff 2016). Such investigations will put to rest the condescending idea that Northerners are the ones safeguarding linguistic diversity through LDD and LEL research. Africans' cultural and linguistic resilience in the face of (post)colonial interventions is doing that. Studying how Africans inhabit and imagine their interactional spaces beyond Northern stereotypes of language offers new directions radically moving away from colonial paradigms, and increases the chance of Africans and Northerners jointly shaping this research, despite continuing inequalities. The benefits of this research would be universal and local; and they would include, not the least, a lesson to the North under which conditions small languages, which we have successfully eradicated in our linguistic monocultures, can thrive.

\section{Acknowledgements}

As always, I am deeply thankful to the Crossroads research participants in Senegal, who ground my perspective on African language practices, and to the Crossroads research team, who critically enrich 
it. I am particularly indebted to Rachel Watson's research and our ongoing discussions on language and languaging. Where I report personal research in this chapter, it has been funded by the VW Foundation DoBeS Programme and by a Leverhulme Trust Research Leadership Award Grant. I gratefully acknowledge both funders' generous support.

\section{References}

Ameka, Felix K. 2015. Unintended consequences of methodologial and practical responses to language endangerment in Africa. In Essegbey, James, Henderson, Brent, Mc Laughlin, Fiona (ed.), Language documentation and endangerment in Africa, 15-35. Amsterdam/Philadelphia: John Benjamins.

Amselle, Jean-Loup. 1990. Logiques métisses. Anthropologie de l'identité en Afrique et ailleurs. Paris: Payot.

Asfaha, Yonas M. \& Kasper Juffermans (eds.) 2014. African literacies. Cambridge: Cambridge Scholars.

Auer, Peter. 2007. The monolingual bias in bilingualism research, or: why bilingual talk is (still) a challenge for linguistics. In Monika Heller (ed.), Bilingualism: A social approach, 319-339: Palgrave Macmillan.

Barbieri, Chiara, Mark Whitten, Klaus Beyer, Henning Schreiber, Mingkun Li \& Brigitte Pakendorf. 2012. Contrasting maternal and paternal histories in the linguistic context of Burkina Faso. Molecular biology and evolution 29(4): 1213-1223.

Batibo, Herman. 2005. Language decline and death in Africa: causes, consequences and challenges. Clevedon: Multilingual Matters.

Berliner, David. forthcoming. Can anything become heritage? In Van de Port, Mattijs \& Birgit Meyer (eds.), Heritage dynamics: politics of authentication, aesthetics of persuasion and the cultural production of the real.

Berliner, David. 2014. On exonostalgia. Anthropological Theory 14(4): 373-386.

Beyer, Klaus. 2010. Language contact and change: a look at social factors in an African rural environment. Journal of Language Contact THEMA 3: 131-152.

Blench, Roger M. 2007. Endangered languages in West Africa. In Matthias Brenzinger (ed.), Language diversity endangered (Mouton Reader), 140-162. Berlin/Boston: De Gruyter Mouton.

Blommaert, Jan. 2006. Writing as a problem: African grassroots writing, economies of literacy, and globalization. Language in Society 33(05): 643-671.

Blommaert, Jan. 2008. Artefactual ideologies and the textual production of African languages. Language \& Communication 28(4): 291-307.

Blommaert, Jan. 2010. The sociolinguistics of globalization. Cambridge: Cambridge University Press.

Blommaert, Jan \& Ben Rampton. 2011. Language and superdiversity. Diversities 13(2): 1-22.

Bodomo, Adams, Jemima Anderson \& Josephine Dzahene-Quarshie. 2009. A kente of many colours: multilingualism as a complex ecology of language shift in Ghana. Sociolinguistic Studies 3(3): 357-379.

Bonfiglio, Thomas P. 2010. Mother tongues and nations. The invention of the native speaker. Berlin/Boston: De Gruyter Mouton.

Brenzinger, Matthias. 1992. Language death. Factual and theoretical explorations with special reference to East Africa. Contributions to the sociology of language 64.

Brindle, Jonathan. 2015. Why is Chakali still spoken? Afrikanistik und Ägyptologie Online.

Brumann, Christoph \& David Berliner. 2016. Introduction: UNESCO world heritage - grounded? In Christoph Brumann \& David Berliner (eds.), World heritage on the ground: Ethnographic perspectives (EASA series 28), 1-34. New York: Berghahn.

Canut, Cécile. 2010. De l'Afrique des langues à l'Afrique des discours. Les voix du langagiaire. Cahiers d'Études Africaines 198-199-20(2-3-4) : 1163-1189.

Childs, G. T. Forthcoming (2017). Busy intersections. A framework for revitalization. In Jason Kandybowicz \& Harold Torrence (eds.), Africa's endangered languages: documentary and theoretical approaches. Oxford: Oxford University Press. 
Childs, G. Tucker, Jeff Good, and Alice Mitchell. 2014. Beyond the ancestral code: towards a model for sociolinguistic language documentation. Language Documentation and Conservation 8:168191.

Cobbinah, Alexander, Abbbie Hantgan, Friederike Lüpke \& Rachel Watson. 2016. Carrefour des langues, carrefour des paradigmes. In Michelle Auzeanneau (ed.), Pratiques plurilingues, mobilités et éducation, 79-97. Paris: Édition des Archives Contemporaines.

Connell, Bruce. 2007. Endangered languages in Central Africa. In Matthias Brenzinger (ed.), Language diversity endangered (Mouton Reader), 163-178. Berlin/Boston: De Gruyter Mouton.

Connell, Bruce. 2015. The role of colonial languages in language endangerment in Africa. In Essegbey, James, Henderson, Brent, Mc Laughlin, Fiona (ed.), Language documentation and endangerment in Africa, 107-129. Amsterdam/Philadelphia: John Benjamins.

Cummins, Jim. 2008. Teaching for transfer: challenging the two solitudes assumption in bilingual education. In Jim Cummins \& Nancy H. Hornberger (eds.), Encyclopedia of language and education, 66-75. New York: Springer.

Cysouw, Michael \& Jeff Good. 2013. Languoid, doculect and glossonym: formalizing the notion 'language'. Language Documentation and Conservation 7: 331-359.

Deumert, Ana. 2014. Sociolinguistics and mobile communication. Edinburgh: Edinburgh University Press.

Deumert, Ana \& Kristin V. Lexander. 2013. Texting Africa: Writing as performance. Journal of Sociolinguistics 17(4): 522-546.

Deumert, Ana \& Anne Storch. forthcoming. Language as world heritage? Critical perspectives on language-as archive.

Di Carlo, Pierpaolo. 2011. Lower Fungom linguistic diversity and its historical development: Proposals from a multidisciplinary perspective. Africana Linguistica 17: 53-100.

Di Carlo, Pierpaolo, Jeff Good \& Rachel O. Diba. 2016. Multilingualism in rural Africa. In Mark Aronoff (ed.), Oxford research enclopedia of linguistics. Oxford: Oxford University Press.

Dimmendaal, Gerrit J. 2008. Language ecology and linguistic diversity on the African continent. Language and linguistics compass 2(5): 840-858.

Dimmendaal, Gerrit J. 2015. Different cultures, different attitudes: but how different is "the African situation" really? In Essegbey, James, Henderson, Brent, Mc Laughlin, Fiona (ed.), Language documentation and endangerment in Africa, 37-57. Amsterdam/Philadelphia: John Benjamins.

Dimmendaal, Gerrit J. \& F. K. E. Voeltz. 2007. Endangered languages of Africa and the Middle East. In Christopher Moseley (ed.), Encyclopedia of the world's endangered languages, 579-634. London: Routledge.

Dingemanse, Mark. 2011. The meaning and use of ideophones in Siwu. Nijmegen: MPI Series in Psycholinguistics.

Djité, Paulin G. 2008. The sociolinguistics of development in Africa. Clevedon: Multilingual Matters.

Djité, Paulin G. 2009. Multilingualism: the case for a new research focus. International Journal of the Sociology of Language 2009(199): 1-7.

Dorian, Nancy C. (ed.) (1989). Investigating obsolescence: studies in language contraction and death. Cambridge: Cambridge University Press.

Duchêne, Alexandre \& Monica Heller (eds.) (2007). Discourses of endangerment. London/New York: Continuum.

Essegbey, James A. 2015. "Is this my language?" Developing a writing system for an endangeredlanguage community. In Essegbey, James, Henderson, Brent, Mc Laughlin, Fiona (ed.), Language documentation and endangerment in Africa, 153-176. Amsterdam/Philadelphia: John Benjamins.

Fardon, Richard \& Graham Furniss (eds.) (1994). African languages, development and the state. London: Routledge.

Gal, Susan. 2016. Scale-making: Comparison and perspective as ideological projects. In E. S. Carr \& Michael Lempert (eds.), Scale: Discourse and dimensions of social life, 91-111. Oakland, CA: University of California Press.

García, Ofelia \& Li Wei. 2014. Translanguaging: Language, bilingualism and education. Basingstoke [England]: Palgrave Macmillan.

Green, David W. \& Jubin Abutalebi. 2013. Language control in bilinguals: The adaptive control hypothesis. Journal of Cognitive Psychology 25(5): 515-530. 
Grinevald, Colette \& Chris Sinha. 2016. North-South relations in lingustic science. Collaboration or colonialism? In Luna Filipović \& Martin Pütz (eds.), Endangered languages and languages in danger. Issues of documentation, policy, and language rights, 25-43. Amsterdam/Philadelphia: John Benjamins.

Güldemann, Tom. 2008. The Macro-Sudan belt: towards identifying a linguistic area in northern subSaharan Africa. In Bernd Heine \& Derek Nurse (eds.), A linguistic geography of Africa, 151-185. Cambridge: Cambridge University Press.

Gumperz, John J. 1962. Types of linguistic communities. Anthropological Linguistics 4(1): 28-40.

Haspelmath, Martin. forthcoming (2017). Some principles for language names. Language Documentation and Conservation.

Hill, Jane H. 2002. "Expert rhetorics" in advocacy for endangered languages: who is listening, and what do they hear? Journal of Linguistic Anthropology 12(2): 119-133.

Himmelmann, Nikolaus P. 1998. Documentary and descriptive linguistics. Linguistics 36. 161-195.

Irvine, Judith T. 2016. Going upscale: scales and scale-climbing as ideological projects. In E. S. Carr \& Michael Lempert (eds.), Scale: Discourse and dimensions of social life, 213-231. Oakland, CA: University of California Press.

Irvine, Judith T. \& Susan Gal. 2000. Language ideology and linguistic differentiation. In Paul V. Kroskrity (ed.), Regimes of language, 35-83. Santa Fe: School of American Research Press.

Juffermans, Kasper. 2015. Local languaging, literacy and multilingualism in a West African society. Bristol: Multilingual Matters.

Juillard, Caroline. 2005. Hétérogénéité des plurilinguismes en Afrique à partir du terrain Sénégalais. La Linguistique 41: 23-36.

Kroskrity, Paul V. 2007. Language ideologies. In Alessandro Duranti (ed.), Companion to linguistic anthropology, 496-517. Malden: Blackwell.

Légère, Karsten. 2007. Vidunda (G38) as an endangered language? In Doris L. Payne \& Jaime Peña (eds.), Selected proceedings of the 37th annual conference on African linguistics, 43-54.

Somerville, MA: Cascadilla Proceedings Project.

Lentz, C. 1995. ' Tribalism' and ethnicity in Africa. Cahiers des Sciences Humaines 31(2) : 303-328.

Lüpke, Friederike. in preparation. Organic multilingualism.

Lüpke, Friederike. 2004. Language planning in West Africa -- who writes the script? Language Documentation and Description 2: 90-107.

Lüpke, Friederike. 2009. At the margin. African endangered languages in the context of global endangerment discourses. African research and documentation 109: 15-41.

Lüpke, Friederike. 2010a. Multilingualism and language contact in West Africa: towards a holistic perspective. Journal of Language Contact THEMA 3: 1-12.

Lüpke, Friederike. 2010b. Rare and endangered - languages or features? An African perspective. Journal of West African Languages XXXVII. 119-139.

Lüpke, Friederike. 2011. Orthography development. In Peter K. Austin \& Julia Sallabank (eds.), The Cambridge handbook of endangered languages, 312-336. Cambridge: Cambridge University Press.

Lüpke, Friederike. 2015. Ideologies and typologies of language endangerment in Africa. In Essegbey, James, Henderson, Brent, Mc Laughlin, Fiona (ed.), Language documentation and endangerment in Africa, 59-105. Amsterdam/Philadelphia: John Benjamins.

Lüpke, Friederike. 2016a. Pure fiction - the interplay of indexical and essentialist ideologies and heterogeneous practices: A view from Agnack. Language Documentation and Conservation Special Publication 10: 8-39.

Lüpke, Friederike. 2016b. Uncovering small-scale multilingualism. Critical Multilingualism Studies 4(2): 35-74.

Lüpke, Friederike. Forthcoming a. Escaping the tyranny of writing: West African regimes of writing as a model for multilingual literacy. In Kasper Juffermans \& Constanze Weth (eds.), The tyranny of writing revisited. London: Bloomsbury.

Lüpke, Friederike. Forthcoming b. Multiple choice: language use and cultural practice in rural Casamance between syncretism and diversity. In Jaqueline Knörr \& Filho, Wilson Trajano Filho (eds.), Creole languages and postcolonial diversity. Leiden: Brill. 
Lüpke, Friederike. Forthcoming c. Supporting vital repertoires, not revitalizing languages. In Leanne Hinton (ed.), The Routledge handbook of language revitalization. Abingdon: Routledge.

Lüpke, Friederike. Forthcoming d. African(ist) perspectives on vitality: fluidity, small speaker numbers and adaptive multilingualism make vibrant ecologies. Language.

Lüpke, Friederike \& Anne Storch. 2013. Repertoires and choices in African languages. Berlin/New York: Mouton de Gruyter.

Marten, Lutz \& Malin Petzell. 2016. Linguistic variation and the dynamics of language documentation: Editing in 'pure' Kagulu. Language Documentation and Conservation (Special Publication 10): 105-129.

Martin-Jones, Marilyn, Sjaak Kroon \& Jeanne Kurvers. 2011. Multilingual literacies in the global south: language policy, literacy learning and use. Compare: a journal of comparative and international education 41(2): 157-164.

Mbembe, Achille. ms. Decolonizing knowledge and the question of the archive.

Mc Laughlin, Fiona. 2015. Can a language endanger itself? Reshaping repertoires in urban Senegal. In Essegbey, James, Henderson, Brent, Mc Laughlin, Fiona (ed.), Language documentation and endangerment in Africa, 131-151. Amsterdam/Philadelphia: John Benjamins.

Mc Laughlin, Fiona. 2008. The ascent of Wolof as an urban vernacular and national lingua franca in Senegal. In Cécile Vigouroux \& Salikoko S. Mufwene (eds.), Globalization and language vitality: perspectives from Africa, 142-170. London: Continuum.

Mcgill, Stuart \& Peter K. Austin. 2012. Introduction. In Peter K. Austin \& Stuart Mcgill (eds.), Language Documentation and Description (11), 5-27: SOAS, University of London.

Mignolo, Walter D. 1996. Linguistics maps, literary geographies, and cultural landscapes: languages, languaging, and (trans)nationalism. Modern Language Quarterly 57(2). 181-196.

Milroy, Lesley. 1980. Language and social networks, 2nd edn. London, Baltimore: Basil Blackwell; University Park Press.

Moore, Leslie C. 2004. Multilingualism and second language acquisition in the northern Mandara mountains. In George Echu \& Samuel Gyasi (eds.), Africa meets Europe: language contact in West Africa, 131-148. New York: Nova Science.

Mous, Maarten. 2003. Loss of linguistic diversity in Africa. In Mark Janse \& Sijmen Tol (eds.), Language death and language maintenance: theoretical, practical and descriptive approaches, 157-170. Amsterdam/Philadelphia: John Benjamins.

Mufwene, Salikoko S. forthcoming. Language vitality: the weak theoretical underpinnings of what can be an exciting research area. Language.

Mufwene, Salikoko S. 2016. A cost-and-benefit approach to language loss. In Luna Filipović \& Martin Pütz (eds.), Endangered languages and languages in danger. Issues of documentation, policy, and language rights, 115-143. Amsterdam/Philadelphia: John Benjamins.

Newman, Paul. 2003. The endangered languages issue as a hopeless cause. In Mark Janse \& Sijmen Tol (eds.), Language death and language maintenance: theoretical, practical and descriptive approaches, 1-13. Amsterdam/Philadelphia: John Benjamins.

Ngué Um, Emmanuel. 2015. Some challenges of language documentation in African multilingual settings. In Essegbey, James, Henderson, Brent, Mc Laughlin, Fiona (ed.), Language documentation and endangerment in Africa, 195-212. Amsterdam/Philadelphia: John Benjamins.

Perley, Bernard C. 2012. Zombie linguistics: experts, endangered languages and the curse of undead voices. Anthropological Forum 22(2): 133-149.

Piller, Ingrid. 2016. Monolingual ways of seeing multilingualism. Journal of Multicultural Discourses 11(1): 25-33.

Quint, Nicolas. forthcoming (2017). Djifanghor Nyun (Bainouck). In Friederike Lüpke (ed.), The Oxford guide to the Atlantic languages of West Africa. Oxford: Oxford University Press.

Ranger, Terence. 1983. The invention of tradition in colonial Africa. In Eric J. Hobsbawm \& Terence O. Ranger (eds.), The invention of tradition, 211-262. Cambridge: Cambridge University Press.

Rohloff, Peter \& Brent Henderson. 2015. Development, language revitalization, and culture: The case of the Mayan languages of Guatemala, and their relevance for African languages. In Essegbey, James, Henderson, Brent, Mc Laughlin, Fiona (ed.), Language documentation and endangerment in Africa, 177-194. Amsterdam/Philadelphia: John Benjamins.

Rosch, Eleanor H. 1973. Natural categories. Cognitive Psychology 4: 328-350. 
Sands, Bonny. Forthcoming. Language revitalization in Africa. In Kenneth Rehg \& Lyle Campbell (eds.), The Oxford handbook of endangered languages. Oxford: Oxford University Press.

Schreiber, Henning. 2009. Social networks, linguistic variation and micro change in an African context. A case study in the borderland of Mali and Burkina Faso. SUGIA 20: 209-230.

Schultze-Berndt, Eva. 2006. Linguistic annotation. In Jost Gippert, Nikolaus Himmelmann \& Ulrike Mosel (eds.), Essentials of language documentation, 213-251. Berlin/New York: Mouton de Gruyter.

Seifart, Frank. 2006. Orthography development. In Jost Gippert, Nikolaus Himmelmann \& Ulrike Mosel (eds.), Essentials of language documentation, 275-300. Berlin/New York: Mouton de Gruyter.

Silverstein, Michael. 2003. Indexical order and the dialectics of sociolinguistic life. Language \& Communication 2:. 193-229.

Simons, Gary F. \& Charles D. Fenning (eds.) (2017). Ethnologue: languages of the world. Dallas, Texas: SIL International.

Singer, Ruth \& Salome Harris. forthcoming. What practices and ideologies support small-scale multilingualism?: A case study of unexpected language survival in an Australian Indigenous community. International Journal for the Society of Language.

Storch, Anne, Johannes Harnischfeger \& Rudolf Leger (eds.) (2014). Fading delimitations: Multilingual settlements in a convergence area: case studies from Nigeria (Topics in interdisciplinary African studies volume 34). Köln: Rüdiger Köppe.

Swaan, Abram de. 2001. Words of the world: The global language system. Cambridge: Polity.

Thomason, Sarah G. 2016. Language contact and change in the Americas: The state of the art. In Andrea L. Berez-Kroeker, Diane M. Hintz \& Carmen Jany (eds.), Language contact and change in the Americas: Studies in honour of Marianne Mithun, 1-13. Amsterdam/Philadelphia: John Benjamins.

Trudgill, Peter. 2011. Sociolinguistic typology: Social determinants of linguistic complexity. Oxford: Oxford University Press.

UNESCO. 2003. Language vitality and endangerment: Document adopted by the international expert meeting on UNESCO programme safeguarding of endangered languages of the ad hoc expert group on endangered languages.

UNESCO. 2011. UNESCO's language vitality and endangerment methodological guideline: Review of application and feedback since 2003. UNESCO's culture sector for expert meeting "Towards UNESCO guidelines on language policies: a tool for language assessment and planning" (30 May 1 June 2011).

UNESCO. 2016. Literacy in multilingual and multicultural contexts: Effective approaches to adult learning and education: UNESCO Institute for Lifelong Learning.

van Beek, Walter, R. M. Bedaux, Suzanne P. Blier, Jacky Bouju, Ian Crawford, Mary Douglas, Paul Lane, Claude Meillassoux \& Marcel Griaule. 1991. Dogon restudied: a field evaluation of the work of Marcel Griaule [and comments and replies]. Current Anthropology 32(2): 139-167.

Vigouroux, Cécile \& Salikoko S. Mufwene. 2008. Globalization and language vitality: perspectives from Africa. In Cécile Vigouroux \& Salikoko S. Mufwene (eds.), Globalization and language vitality: perspectives from Africa, 1-31. London: Continuum.

Watson, Rachel. in preparation. Language as category.

Wenger, Etienne. 2000. Communities of practice. New York: Cambridge University Press.

Wolff, Ekkehard. 2016. Language and development in Africa. Cambridge: Cambridge University Press.

Woodbury, Anthony C. 2003. Defining documentary linguistics. Language Documentation and Description 1: 35-51.

Woodbury, Anthony C. 2005. Ancestral languages and (imagined ) creolisation. Language Documentation and Description 3: 252-262.

Woodbury, Anthony C. 2011. Language documentation. In Peter K. Austin \& Julia Sallabank (eds.), Handbook of endangered languages, 159-186. Cambridge: Cambridge University Press. 